\title{
Veronika Koller* and Marlene Miglbauer What Drives the Right-Wing Populist Vote? Topics, Motivations and Representations in an Online Vox Pop with Voters for the Alternative für Deutschland
}

https://doi.org/10.1515/zaa-2019-0024

Abstract: In a recent study (Miglbauer, Marlene and Veronika Koller (2019). “'The British People have Spoken': Voter Motivations and Identities in Vox Pops on the British EU Referendum.” Veronika Koller, Susanne Kopf and Marlene Miglbauer, eds. Discourses of Brexit. Abingdon: Routledge, 86-103.), we investigated vox pops (short for 'vox populi,' i.e. 'voice of the people') with self-declared Leave voters in the run-up to the 2016 British EU referendum. The study presented here complements this research with a comparative perspective, exploring the motivations expressed by voters for the German right-wing populist party AfD (Alternative für Deutschland). On the day of the 2017 general election, the German news website Zeit online (ZON) invited its readers to say why they voted AfD. Although the AfD voter profile and the $\mathrm{ZON}$ readership profile are noticeably different, the question elicited 468 replies numbering a total of around 59,000 words, which we compiled into a corpus. Working with corpus analysis software AntConc 3.4.1w, we first prised out topics and motivations by analysing this collection of online vox pops for word frequencies as well as collocates and concordances for selected lexical units, before manually grouping the different lexemes into ten topics. In a second step, we manually analysed the data for social actor representation (van Leeuwen, Theo (2008). Discourse and Practice: New Tools for Critical Discourse Analysis. Oxford: Oxford University Press.) and appraisal (Martin, James R. and Peter R. R. White (2005). Appraisal in English. Basingstoke: Palgrave Macmillan.). The results of the analysis show that next to previously documented motivations for right-wing populist votes - e.g. in-group bias and rejection of the Other as morally deficient (Heinisch, Reinhard (2008). "Austria: The Structure and Agency of Austrian Populism.” Daniele Albertazzi and Duncan McDonnell, eds. Twenty-First Century Populism: The Spectre of Western European Democracy. Basingstoke: Palgrave Macmillan, 67-83.) -, the group of AfD voters represented in the written vox pop have specific additional reasons, namely a focus on German chancellor Merkel as an 'anti-hero' and a belief of being victimised by the media.

\footnotetext{
*Corresponding author: Veronika Koller: Lancaster University, Lancaster, UK, e-mail:v.koller@lancaster.ac.uk

Marlene Miglbauer: University College of Teacher Education Burgenland, Eisenstadt, Austria
}

○ Open Access. (C) 2019 The Author(s), published by De Gruyter. (c) BY This work is licensed under the Creative Commons Attribution 4.0 International License. 
An additional, unexpected finding was that a number of posters to the dedicated comment forum explicitly distance themselves from perceived stereotypes of right-wing populist voters. Our findings therefore also problematise previously identified characteristics of right-wing populist discourse as anti-elitist and antiintellectual (Wodak, Ruth (2015b). The Politics of Fear: What Right-Wing Populist Discourses Mean. Los Angeles: SAGE.) and call into question the support from workers, and associated fears of wage pressure and competition for welfare benefits, as one of the main factors in the success of right-wing populism (Oesch, Daniel (2008). “Explaining Workers' Support for Right-Wing Populist Parties in Western Europe: Evidence from Austria, Belgium, France, Norway, and Switzerland.” International Political Science Review 29.3, 349-373.).

Keywords: Alternative für Deutschland (AfD); discourse analysis; populism; vox pops.

\section{Introduction}

In this paper, we look at the motivations constructed by voters for the German right-wing populist party $\mathrm{AfD}$ (Alternative für Deutschland/Alternative for Germany) on a comments page that the news website Zeit online (ZON) opened after polls closed in Germany's 2017 general election. The website asked its readers why they had voted $A f D$, which triggered 468 replies comprising around 59,000 words. We regard this data as an example of an online vox pop, a subgenre that sits at the interface between video or audio vox pops on the one hand and readers' comments on news sites on the other.

Vox pops (short for 'vox populi,' i.e. 'voice of the people') are a form of spontaneous micro-interaction between journalists and wo/men on the street that has been defined as 'interview fragments with ordinary people expressing their opinions on a particular issue in their own words' (Lewis et al. 2005, 70). Next to their brevity - they often comprise no more than three turns at most (Tolson 2019, 423) -, their typical feature is therefore not so much on what is said but on 'what does someone like you say' (Myers 2004, 209). Our data are somewhat different though: while the form in which the comments were elicited ('Why did you vote AfD?') designated a particular group of respondents even more so than conducting vox pops in particular areas where journalists expect to find certain types of voters, we assume that the ZON journalists were driven by a genuine interest in readers' answers. As we elaborate below (Section 4), the typical reader profile for the news website is different from that of AfD voters and the dedicated comment space can be seen as an attempt to understand the Other. Moreover, our data are 
not typical of vox pops in that they are online texts. They are very much elicited though, making them better candidates for the genre of vox pops than unsolicited tweets (Beckers and Harder 2016) or readers' comments. Precisely because they are online texts, they show the 'variations in the vox pop format which allow for the production of different types of statement' (Tolson 2019, 422).

In investigating an online vox pop with voters for a right-wing populist party, the present study complements previous work we did on video vox pops with self-declared Leave voters in the run-up to the 2016 British EU referendum (Miglbauer and Koller 2019). In particular, we seek to answer the following research questions:

RQ1: What topics and motivations are made relevant by people voting AfD in the 2017 general election in Germany?

RQ2: How do AfD voters represent and evaluate social actors?

RQ3: Do the findings suggest reasons for supporting right-wing populist politics that are shared across contexts?

In the remainder of the article, we will first discuss existing research on right-wing populism and the motivation of voters to cast their ballot for relevant parties, causes and candidates. Following those theoretical considerations, the third section provides background information on the AfD, comparing and contrasting it with UKIP and the Brexit Party, before we elaborate on our data and methods in Section 4. That section also includes a profile of AfD voters as contrasted with $\mathrm{ZON}$ readers. The central part of the article is Section 5, in which we present our analysis of topics and motivations, social actor representation and appraisal in the voters' comments. Section 6 concludes the study by discussing in how far the findings are similar to, or different from, the motivations of Leave voters in the UK.

\section{Populism and Voter Motivation}

In recent years, 'populism' has become a political buzzword and a research focus in several disciplines, including political science, sociology and linguistics. Depending on the field and focus of research, populism has been defined and approached differently, but in this paper, we regard populism as both an ideology and a discursive strategy.

Mudde and Kaltwasser $(2017,6)$ refer to populism as a

thin-centered ideology that considers society to be ultimately separated into two homogeneous and antagonistic camps, "the pure people" versus "the corrupt elite," and which argues that politics should be an expression of the volonté générale (general will) of the people. 
Albertazzi and McDonnell's definition also refers to populism as an ideology but adds that the sovereign people are also pitted against "dangerous "others" who are [along with the elite] depicted as depriving (or attempting to deprive) the sovereign people of their rights, values, prosperity, identity and voice' $(2008,3)$.

Approaching populism as an ideology, or more specifically a thin-centred ideology, means that populism is usually linked to 'thick-centred' or 'full' ideologies and their ideas about society and its purposes, which are essential for promoting political movements to the people (Mudde and Kaltwasser 2017, 6). In order to promote elements of an ideology and appeal to the electorate, however, populism needs to be conveyed to the people as well. Therefore, we also approach populism as a discursive strategy, which can be defined as a 'latent set of ideas or a worldview ... manifested in distinct linguistic forms and content that have real political consequences' (Hawkins 2009, 1045). As such, it is a mode of political expression employed selectively and strategically by politicians (Kazin 1995).

Depending on the elements of the ideology, or even ideologies, that populist parties draw upon, these parties are either defined as left-wing or right-wing. In recent decades the term 'populism' has primarily been used for right-wing populism (but see e.g. Demata (2019) for an account of left-wing populism), due to the emergence of parties and movements on the right of the political spectrum in Europe since the 1980s (Decker 2008, 122). Right-wing populism displays several inherent principles (Freeden 2017, 4; Heinisch 2008, 43; Inglehart and Norris 2016, 6-7; Wodak 2015a,b). These include a strong emphasis on nativist and revisionist tendencies, as society is regarded as ideally homogeneous and in need of protection from any outside danger or threat from within. While the latter emanates from 'enemies in their midst' (Freeden 2017, 4), notably (corrupt) political elites and intellectuals, the former is posed by immigrants triggering fears of economic inequality (Inglehart and Norris 2016) and of the native population no longer being 'masters in their own homes' (Albertazzi and McDonnell 2008, 6).

In order to overcome such fears and perceived threats, voters particularly support "politicians who know (rather than "listen to") the people, and who make their wishes come true' (Mudde 2004, 558), i.e. politicians whom voters can trust, who give them hope and who claim to govern in the interest of the people. Such a charismatic bond between leaders and followers is crucial for populist parties, which tend to be ideologically flexible as well as authoritarian and messianic. Freeden $(2017,5)$ aptly points out that 'right-wing populism is not a grassroots phenomenon ... aggressive populist leadership filters, articulates, shapes and streamlines ... some of the worries of the "people” in whose name they speak.' Right-wing populist leaders therefore seek to be regarded as belonging to the group of ordinary people and to achieve this perception, they move beyond conventional styles of communication and language use (Albertazzi and McDonnell 
2008, 7). Such a break with the conventions of political communication has sparked interest in political and media discourse studies (e.g. Wodak 2015a,b; Wodak et al. 2013). The present paper complements these previous studies in that its focus is not on analysing politicians' language use, but the voices of voters. In particular, we are interested in what topics and motivations are made relevant by voters, and how they represent and evaluate specific social actors (e.g. individual politicians). Beyond that, we want to know if AfD voters name reasons for supporting the party that have also been documented for other contexts. This focus additionally helps build a bridge between populism being perceived as an ideology (Albertazzi and McDonnell 2008; Mudde and Kaltwasser 2017) and as a discursive strategy (Hawkins 2009; Jowett and O’Donnell 2015; Kazin 1995), as our analysis of linguistic markers brings together linguistic and socio-political concepts.

In the past, one of the most decisive factors for voter motivation in elections used to be party allegiance according to class and other social structural variables, which ensured votes for traditional parties. Yet, as Western societies experienced diversification and increased liberalisation of society, topics - so-called short-term factors - became increasingly relevant to voters at elections. Consequently, there was a shift from party allegiance to short-term factors being decisive for voter motivation (Denver et al. 2012; Kritzinger et al. 2013). Traditional parties turned out to be slow in their response to issues such as economic and cultural globalisation, immigration, the environment, European integration and the decline in class-based politics and ideologies (Albertazzi and McDonnell 2008, 1; Inglehart and Norris 2016). This lack of an adequate response enabled new parties to be founded on both the left and the right of the political spectrum. In particular, right-wing populist parties have entered the (European) political stage by successfully focussing on the short-term factor of immigration.

Research has disclosed three main factors of motivation to support right-wing populist parties in Europe: fear of wage pressure and competition for welfare benefits through immigration, the perception of immigration as a threat to national identity, and discontent with a perceived lack of democracy (Heinisch 2008; Mayer and Perrineau 1992; Oesch 2008; Spruyt et al. 2016). Among these, antiimmigrant attitudes and dissatisfaction with a country's politics tend to be the main driving forces (Billiet and Witte 1995; Lubbers and Scheepers 2000).

During the 2010s, right-wing populist parties gained a foothold in several European countries, such as the AfD in Germany and UKIP in the UK. The latter, and its de facto successor, the Brexit Party, is essentially a one-issue party that wants the UK to leave the European Union and channels a number of insecurities and resentments to reach its goal. In 2014, the BBC news website represented a small number of UKIP voters talking about their motivations ('Why I voted UKIP' 2014), a feature not unlike the data we analyse in this article. The UKIP voters in 
the feature, all of whom identified as working-class, named two main reasons for supporting the party: 'mass' or 'uncontrolled' immigration, which they saw as 'depressing the working-class standard of living in this country' and putting a strain on the benefits system, and wanting to 'encourage the main parties to offer an in or out vote on Europe'. Wishing to maintain British culture, which was perceived as being under threat, and being frustrated with 'career politicians' were also named as motivations. Interestingly, most of them did not actually wish to leave the EU, which is at odds with the raison d'être of UKIP but shows the party's potential to garner protest votes.

Apart from the UK-specific aspect of a referendum on EU membership, AfD voters seem to share most motivations with their counterparts across the Channel: one prominent reason is again immigration, especially the perceived cultural threat of Muslim migrants and wariness about pressures on the welfare system. Similar to UKIP voters, AfD supporters also wish to register their protest against established parties (Pfahl-Traughber 2017; Storz and Kahrs 2016). In the next section, we will provide some background information on the AfD and its voters.

\section{The Alternative für Deutschland (AfD) and its Voters}

The AfD is a relative newcomer to the party political landscape in Germany. Founded in February 2013, it narrowly missed the minimum five percent required for seats in the federal parliament in the general election that year. However, its representatives were first elected to a state parliament in the state of Saxony in 2014 and in the next general election of 2017, the party secured 12.6 percent of the vote. This electoral success precipitated a crisis within the party that saw, over the course of three months, the resignation of federal party co-leader Frauke Petry along with 19 AfD politicians in different states of Germany. Nevertheless, by 2018, the party held seats in all of Germany's 16 state parliaments (Statista 2019) and came fourth, at 11 percent, in the European elections in 2019. Its strongest voter base continues to be in the Eastern states, especially Saxony.

The AfD has a small but growing membership, recording 33,651 members at the beginning of 2019 (AfD 2019). In 2017 (most recent figures available), its voter profile showed a clear gender bias, with 69 percent male voters, as well as a comparatively low popularity with young voters: only 11 percent of its voters are in the 18-29 age bracket, while 46 percent are 30-54 and another 43 percent are $55+$. The average monthly net income of those voters is, at $€ 2500$, close to the German 
average of $€ 2750$, and 46 percent of voters are white-collar workers, followed by 34 percent blue-collar workers and 14 percent self-employed voters (DIW 2017; Kwasniewski 2017). Right-wing populist parties are often perceived as predominantly attracting low-income men (Storz and Kahrs 2016), but as far as economic factors are concerned, this is clearly not the case for the AfD. Our study will show that such perceptions are also explicitly contested by some AfD voters.

In the preamble to its manifesto (AfD 2016), the AfD refers to its membership as 'liberals and conservatives ... free citizens of our country [and] committed democrats' ('Liberale und Konservative ... freie Bürger unseres Landes [und] überzeugte Demokraten'). ${ }^{1}$ This focus on freedom, democracy and patriotism is elaborated later in the text:

Wir setzen uns mit ganzer Kraft dafür ein, unser Land im Geist von Freiheit und Demokratie grundlegend zu erneuern und eben diesen Prinzipien wieder Geltung zu verschaffen. Wir sind offen gegenüber der Welt, wollen aber Deutsche sein und bleiben. Wir wollen die Würde des Menschen, die Familie mit Kindern, unsere abendländische christliche Kultur, unsere Sprache und Tradition in einem friedlichen, demokratischen und souveränen Nationalstaat des deutschen Volkes dauerhaft erhalten.

[We put all our energy towards fundamentally renewing our country in the spirit of freedom and democracy, and making those principles valid again. We are open to the world, but we want to be and stay Germans. We want to keep and sustain the dignity of all people, families with children, our occidental Christian culture, our language and traditions in a peaceful, democratic and sovereign nation state of the German people.]

It is difficult to find an exact equivalent of the AfD in the UK, because right-wing populist parties in the UK are - as most of politics since 2013 - refracted through the prism of Brexit. The closest equivalent, the UK Independence Party (UKIP), has recently been all but replaced by the Brexit Party. Founded in April 2019 by former UKIP leader Nigel Farage to compete in the European elections, the party has not yet published a manifesto. However, an edited video of the party's launch (The Brexit Party 2019) includes the following spoken contributions from a number of candidates:

I think we have a parliament that is now completely out of touch with our country. I think politics is broken. Our task and our mission is to change politics for good. ... Our political class of all parties have spent their time and efforts, along with their friends in Europe, to create an institutional structure, a political regulation that has depoliticised the economy

1 Given the predominantly male voters for the AfD, it is worth noting that the party manifesto uses "generic" masculine forms throughout. 
and de-democratised politics. Never again ... should we ever, ever allow ourselves to be humiliated in this way [i.e. have to ask the EU for an extension to leaving]. ... This is a battle that we shouldn't be having to fight, but we are having to fight it and we are going to win it.

The UKIP's interim manifesto from September 2018 (UKIP 2018), meanwhile, states that

UKIP will promote and defend our national and individual freedoms. We stand for freedom from the European Union and the right to live once again under our own traditional freedoms and liberties, together with the right once again to be proud of our great country. We are determined to protect our freedom of speech and the right to speak our minds without fear of the politically correct thought-police knocking on our doors.

Clearly, the AfD manifesto is the most comprehensive and carefully crafted of the three texts. Still, the three parties overlap in their claim that politics needs to be renewed and in their focus on freedom, including freedom of speech, democracy and national identity (cf. Kranert, 2019, for a study of similarities and differences between the UKIP and AfD manifestos).

\section{Data and Methodology}

As detailed above (Section 1), our data consists of an online vox pop that was elicited by the news website Zeit online (ZON), which, after exit polls were published on 24 September, the day of the German general election in 2017, asked its readers 'Why did you vote AfD?' ('Warum haben Sie die AfD gewählt?') and opened a dedicated forum where readers could post their replies (ZON 2017). This attracted 529 postings, but as it was not our aim to study the interaction among commenters, we collected only those that did not reply to other readers. This brought the number down to 468 posts, comprising a total of 59,423 words or tokens. In the analysis, quotes from the dataset are provided without any changes, and any non-standard punctuation, spelling and grammar has been kept.

We have mentioned above (Section 3) that AfD voters are predominantly male, with few young voters, and have earnings close to the German average. While this demographic in some respects defies the stereotype of right-wing populist voters, it is also different from typical ZON readers. The latter show more of a gender balance, with 57 percent male readers, and, with 28 percent of readers under the age of 30, are younger than AfD voters. Although there are no data for income, 52 percent of readers have finished secondary school or hold a university degree, and can therefore be assumed to be above-average earners (Schröder 2012). It is 
somewhat surprising then that so many readers contributed to the online vox pop and we might assume that the commenters are not typical AfD voters. We will below discuss what this suggests for the mainstreaming of topics and motivations that are relevant to right-wing populist voters.

In order to identify those topics and motivations and answer our first research question (What topics and motivations are made relevant by people voting AfD in the 2017 general election in Germany?), we used the AntConc 3.4.1w corpus analysis software to generate a list of word frequencies. This resulted in 10,158 different words, or types, of which we disregarded all items with fewer than 10 occurrences. We then manually grouped the remaining 631 types into ten topics and two lexico-semantic categories, namely nouns and conjunctions indicating reasons (e.g. 'Grund' ['reason'], 'weil' ['because']) as well as pronouns to indicate self-reference by the posters. Both topics and pronouns also enabled us to answer our second research question (How do AfD voters represent and evaluate social actors?). We also looked at the collocates of selected lexemes to gain a better understanding of how social actors were represented and evaluated. ${ }^{2}$

To complement and further validate the largely quantitative corpus analysis, we used the collaborative annotation software eMargin to manually fine-code the corpus for content categories, social actor representation (van Leeuwen 2008) and the appraisal of such actors (Martin and White 2005). Both the framework for social actors and the one for appraisal are noteworthy for their complexity, so we will limit our analysis to a selection of sub-systems and categories. For social actor representation, we first of all focused only on included actors, i.e. we disregarded social actors that had been backgrounded or suppressed in the posts, and among those limited ourselves to actors who were most relevant for the question of what drives the right-wing populist vote. For those actors, we looked at how they were personalised or impersonalised, with some sub-categories at finer layers. Thus, personalisation can, with some simplification, be divided into functionalisation - or reference to actors in terms for what they do - and identification, i.e. representing people in terms of what they are. In addition, personalisation can take the form of nomination, where individuals are referred to by their first and/ or second name, alongside any titles. Impersonalisation, on the other hand, can again be stripped of some of its complexity to comprise collectivisation, or the representation of social actors as groups, and aggregation, i.e. referring to groups of people in numerical terms. From Martin and White's (2005) appraisal framework, we took the sub-system of attitude, which consists of (a) judgements, which are typically made of people in terms of how special, capable, resolute,

2 We searched for collocates within a three-word span left and right of the node word. Minimum frequency was 3 and the likelihood score was mutual information (MI). 
moral or honest they are; (b) appreciation, which typically refers to events and objects to evaluate them for their impact, quality, composition, and significance and benefit or harm; and (c) the affect or emotional reaction, such as (un)happiness, (dis)satisfaction, (in)security and (dis)inclination, that is ascribed to social actors, including the text producers themselves.

In the following main section of the article we will demonstrate how we applied these methods to our example of an online vox pop.

\section{Analysis}

The analysis will first address the topics and motivations that posters mention as influencing their decision to vote AfD, thus answering the first research question. We will then proceed to examine how central social actors are represented and evaluated, and thereby answer RQ2. The third research question, pertaining to similarities and differences across national contexts, especially Germany and the UK, will be dealt with in Section 6 .

As detailed in the previous section, our first step was to generate a wordlist, resulting in 631 different words that occurred more than ten times in the corpus. These we grouped into thematic categories, as shown in Table 1. We have ordered the topics by frequency of tokens and given the three most frequent lexemes in brackets. These have been translated from German and comprise different word forms, e.g. 'German*'/'deutsch`' includes 'deutsch' ('German’ [adjective]), 'Deutsche' ('Germans'), 'Deutschland' ('Germany') etc.

The type-token ratio shows that the topic of political actors shows least lexical variety, i.e. the language used by commenters to talk about this topic is repetitive and formulaic. Given how frequently that topic is realised, this lack of variety suggests a high degree of conventionalisation in how AfD voters talk about political actors. At the other end of the scale, we find the topic of gender being lexically varied but realised infrequently.

The results shown in Table 1 assisted both the content analysis of topic and motivations and the linguistic analysis of the representation and evaluation of social actors. It is to the content analysis that we now turn.

\subsection{Topics and Motivations}

In this section we analyse the voters' motivation to cast their vote for AfD in the German general election of 2017. Most of the contributors go into quite a lot of detail on why they voted AfD, making it possible to identify three broad moti- 
Table 1: Topics, types and tokens in the online vox pop.

\begin{tabular}{|c|c|c|}
\hline Topic and most frequently occurring types & $\begin{array}{l}\text { Number of types } \\
\text { and tokens }\end{array}$ & $\begin{array}{l}\text { Type- } \\
\text { token ratio }\end{array}$ \\
\hline Political actors ('AfD,' 'parties,' ‘Merkel') & $\begin{array}{l}26 \text { types } \\
2078 \text { tokens }\end{array}$ & 0.013 \\
\hline $\begin{array}{l}\text { Migration and Islam ('refugees,' 'Islam,' 'refugee } \\
\text { policy') }\end{array}$ & $\begin{array}{l}30 \text { types } \\
899 \text { tokens }\end{array}$ & 0.033 \\
\hline National identity ('German*,' 'country,' 'here’) & $\begin{array}{l}9 \text { types } \\
640 \text { tokens }\end{array}$ & 0.014 \\
\hline General actors ('people,' 'citizens,' 'population') & $\begin{array}{l}6 \text { types } \\
298 \text { tokens }\end{array}$ & 0.020 \\
\hline Europe and EU ('euro,' ‘EU,' ‘Europe*’) & $\begin{array}{l}5 \text { types } \\
183 \text { tokens }\end{array}$ & 0.027 \\
\hline Media ('media,' ‘press,' ‘article’) & $\begin{array}{l}8 \text { types } \\
154 \text { tokens }\end{array}$ & 0.052 \\
\hline Money ('money,' 'billions,' 'costs') & $\begin{array}{l}7 \text { types } \\
111 \text { tokens }\end{array}$ & 0.063 \\
\hline $\begin{array}{l}\text { Silencing of AfD and supporters ('Nazi',' 'opinion,' } \\
\text { 'violence') }\end{array}$ & $\begin{array}{l}3 \text { types } \\
77 \text { tokens }\end{array}$ & 0.039 \\
\hline $\begin{array}{l}\text { Miscellaneous: education, environment, } \\
\text { infrastructure ('education,' 'energy turn,' 'schools') }\end{array}$ & $\begin{array}{l}5 \text { types } \\
58 \text { tokens }\end{array}$ & 0.086 \\
\hline Gender ('values,' 'gender,' ‘women') & $\begin{array}{l}6 \text { types } \\
43 \text { tokens }\end{array}$ & 0.14 \\
\hline
\end{tabular}

vations: discontent with the political system in Germany, and in particular with Chancellor Angela Merkel, anti-immigration sentiment, and the media's treatment of AfD and its supporters.

The main motivation for voting AfD is the politics of the current government. Topics such as the erosion of democracy, lack of political alternatives, the AfD as a viable opposition party, and anti-immigration sentiment are tied in with criticism of Chancellor Merkel and the general political developments in Germany. Merkel as chancellor and head of government is the obvious target of criticism. The idea that Merkel and her government weaken democracy is prevalent in the data and is explained by the voters with reference to, for example, immigration policy, the media attacking the AfD and Merkel being in breach of the law.

(1) Die letzten Jahre waren von einer Aushöhlung der Demokratie und des Rechtsstaates geprägt. Merkel konnte mit einer überwältigenden Mehrheit de facto wie eine Sonnenkönigin regieren.

[The past few years were characterised by an erosion of democracy and the rule of law. Having an absolute majority, Merkel could in fact reign like a Sun Queen.] 
In example (1), Merkel is compared to the Sun King Louis XIV, highlighting the authority Merkel has allegedly had to undermine democracy and the rule of law. Merkel is even portrayed as anti-democratic and as a person who is a danger to democracy and the German electorate. Other writers refer to 'Merkel's mistakes' ('Merkels Fehler'), 'Ms Merkel ha[ving] lost her grip on reality' ('Frau Merkel [hat] jeden Bezug zur Realität verloren'), 'Angela Merkel and her autocratic leadership' ('Angela Merkel und [ihr] selbstherrliche[r] Regierungsstiel') and Merkel being 'a social democrat' ('eine Sozialdemokratin'). The latter is noteworthy because it refers to the discontent with Merkels's actual party, which is the Christian Demcratic Union (CDU) and not the Social Democratic Party (SPD). The commenter clearly feels that Merkel's centrist politics have led to her party giving up its traditional conservative values.

Other voters also voice their discontent with the status quo but instead of listing what they are not satisfied with, they foreground their frustration by presenting the AfD as the only viable alternative to the other parties on the ballot paper.

(2) Meine Wahl der AfD ist eine Protestwahl ... es sollte krachen im politischem Gebälk.

[My vote for the AfD is a protest vote ... I wanted to raise the political roof.]

Example (2) is by someone who can be classified as a protest voter (Mayer and Perrineau 1992), i.e. a person who gives their vote to the party they deem most likely to be able to disrupt the political status quo. The party manifesto as such is not that important for this kind of voter, who may not even agree with it (Storz and Kahrs 2016).

The second main motivation to vote AfD is the voters' anti-immigration stance, or more specifically, the voters' discontent with Chancellor Merkel's immigration policy, particularly since 2015. Merkel is blamed for opening the borders to refugees and risking to destabilise Germany, thus endangering instead of protecting Germans.

(3) Ein weiterer Grund für die AFD spricht, das Frau Merkel bis heute bekräftigt, dass Sie Ihre Entscheidung, die Sie im Sep.2015 getroffen hat, wieder treffen würde. Mit der Entscheidung, die Sie am Bundestag vorbei ... getroffen hat, war ein unkalkulierbares Risiko und somit eine bewusst in Kauf genommene Gefährdung für die innere Sicherheit! ... Sie [haben] Ihren höchsten Auftrag zum Wohle des deutschen Volkes zu handeln und schaden von Ihm abzuwenden sträflich ignoriert!

[Another reason for the AfD is that Ms Merkel even now emphasises that she would take the same decision she took in September 2015. ... This decision, 
which she took ... disregarding parliament brought an incalculable risk and therefore consciously accepted a threat to national security! ... You have criminally neglected your most important task, which is to act in the interest of the German people and avert any damage!]

The commenter here foregrounds the potential impact of immigration on the lives of German people. This focus on 'smaller life worlds,' such as 'personal space, family, and friends, result[ing] in growing concerns about personal safety and security' (Heinisch 2008, 49) influences this voter's decision to vote AfD. Voters sometimes even state which party they used to support but because of all the changes for the worse that they perceive, they decided to vote AfD in the 2017 election. People tell stories from their lives by voicing their discontent about (mostly) Muslim neighbours and their behaviour, as example (4) shows.

(4) Von 1990-2013 konsequenter Grün-Wähler. Diesmal AfD durch ... persönliche Erfahrungswerte wie die geplante Entführung einer Jugendfreundin durch ihren Vater in die Türkei zur Zwangsheirat wegen ihres ‘deutschen' Freundes.

[Voted for the Greens consistently between 1990 and 2013. AfD this time because of ... personal experiences like the father of an old friend planning her abduction to Turkey and a forced marriage because of her 'German' boyfriend.]

In general, commenters express their hope that the AfD will bring about changes to the political system in Germany by, for example, introducing topics that they deem important but that no other party would put on their agenda. The following example is interesting because it stresses the importance of democracy and debate, criticises AfD politicians and voices anti-Muslim sentiment while expressing a pro-European stance. The commenter thereby constructs Islam and Europe as incompatible, while also establishing a hierarchy of migrants.

(5) Ich wählte die AfD, ... - weil ich ein großer Anhänger von Demokratie und offenen Debatten bin - trotz des z.T. schlechten politischen Personals - weil sie als einzige Partei zur Wahl stand, die auch die 'unliebsamen Themen' anspricht - weil mir die unkontrollierte Einwanderung von Muslimen große Sorgen bereitet ... weil ich selber (europäischen) Migrationshintergrund habe, die europäische Kulture liebe und diese erhalten und geschützt haben möchte. [I voted AfD ... because I am a great supporter of democracy and open debate, despite some bad candidates, because it was the only party on the ballot paper that addresses 'uncomfortable topics' as well, because I am very worried about uncontrolled Muslim immigration ...because I am myself a 
(European) migrant, love European culture and want to see it maintained and protected.]

The third main voter motivation pertains to discontent with the media and, in particular, its perceived attempts to silence the AfD and its supporters. Many voters particularly criticise and refute the media's portrayal of AfD voters as 'nazis.'

(6) Danke an die Zeit Redaktion, dass Ihr diese Frage stellt und endlich einen offenen Dialog zulasst. Wer die Kommentare liest, wird schnell feststellen, dass der klassische AfD Wähler kein Nazi ist. "Danke” nochmal an alle Medien, die den AFD Wähler, den Anti-Establishment Wähler, permanent als Nazi oder ähnlich verunglimpft habt.

[Thank you to the Zeit [online]'s editorial staff for asking this question and finally allowing for open dialogue. Whoever reads the comments will soon realise that the typical AfD voter is not a nazi. 'Thank you' again to all media who have constantly vilified the AfD voter, the anti-establishment voter, as a nazi or similar.]

Some voters also explicitly state that the media's negative treatment of the AfD persuaded them to vote for that party.

Although we did not specifically look for identity constructions by the voters, our manual annotation of the vox pop made us realise that AfD voters talking about their motivation in the ZON forum in fact often do identity work. The assumption that AfD supporters are right-wing people is refuted by highlighting their own socio-economic and educational background and making it explicit that they are neither 'nazis' nor racists.

(7) Ich bin weder ostdeutsch, noch schlecht gebildet (Uni-Abschluss), noch alt (24), noch arbeitslos und verdiene über dem Durchschnitt.

[I am neither from Eastern Germany nor poorly educated (university degree), nor old (24), nor unemployed and have above-average earnings.]

(8) Nein, ich bin kein Nazi und auch kein Rassist. ... Ich verdiene 200.000 per anno und sehe mich nicht als sozial abgehängt an. Da ich 4 Sprachen spreche und 2 Hochschulabschlüsse habe, halte ich mich auch nicht für unterbelichtet. [No, I am neither a nazi nor a racist. ... I earn 200,000 a year and do not see myself as left behind. As I speak 4 languages and have 2 university degrees, I don't think of myself as dim either.]

(9) P.S. Gastarbeiter-Kind, Akademiker, überdurchschnittl. Gehalt 
[PS: Child of migrant workers, university degree, above-average salary]

Rather, AfD voters in the ZON online vox pops state that they are frustrated about the social developments in Germany and about traditional parties not reacting adequately to voters' real life worlds and problems.

We will return to what this self-positioning suggests for mainstreaming rightwing populist topics and motivations in our conclusion. For now, we will proceed to the linguistic analysis of how the commenters represent and appraise social actors.

\subsection{Representing and Appraising Social Actors}

The topic categories derived from the initial word list already suggests a number of frequently represented social actors, such as politicians, refugees and the media, which are indeed the three main topics that AfD supporters refer to as motivating their voting decision. However, one of the topics identified is general actors, realised most commonly by the lexemes 'people' ('Menschen,' 'Leute'), 'citizens' ('Bürger') ${ }^{3}$ and the collective 'population' ('Bevölkerung,' 'Volk'). ${ }^{4}$ Looking at 'people,' we can see that it refers not only to unspecified actors (e.g. 'our democracy, for which millions of people had to die'/'unsere Demokratie, für deren Schaffung einst Millionen Menschen sterben mußten'), but also to specific groups of social actors that are indicated by the other topics as well: migrants, politicians and voters. Disregarding compound nouns (e.g. 'first-time voter'/'Erstwähler'), there were 244 references to migrants, 46 to politicians and 86 to voters. ${ }^{5}$ This clearly shows how important migration was to motivate AfD voters.

The different representations of the three groups are shown in Figure 1.

The most commonly used lexeme to refer to migrants in the whole word list is in fact 'refugee ${ }^{\star}$ ' ('Flüchtling ${ }^{\star}$ '), with 99 instances, followed by '^migrant ${ }^{\star}$ ' (“*migrant*') at 42 and 'Asyl*' ('asylum*') at 23 occurrences. (See Gabrielatos and Baker 2008, for a conflation of the terms in the British press.) To this we can add the 80 times that the social actor group is indicated by the word 'people' ('Menschen,' 'Leute'). As a group, migrants are mostly identified in terms of who

3 When used in its plural form, 'Bürger' features as a "generic" masculine. There is only one instance of 'Bürgerin' (feminine singular) and no occurrence of 'Bürgerinnen' (feminine plural). The voters' language use here mirrors that of the party they support (see n. 1).

4 'Bevölkerung' features 42 times, but 'Volk' can also be found 32 times. It should be noted that the former terms carries administrative connotations, while the latter is somewhat tainted by associations with its use during the Nazi regime (cf. also Kranert, 2019).

5 There were two uses of 'Germans' ('Deutsche'”), by the same commenter, where the word referred to voters. 


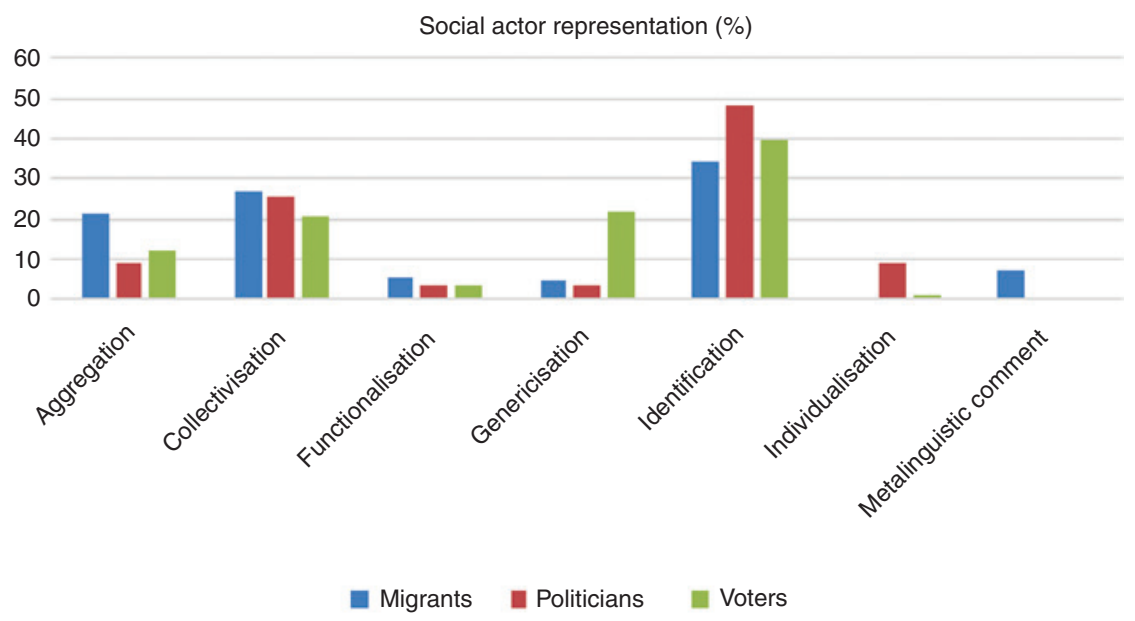

Figure 1: Social representation of migrants, politicians and voters in the online vox pop.

they are (34.24 percent), followed by reference to them as an unspecified collective (26.63 percent) and representation by numbers ( 21.2 percent). They are also the only social actor to attract metalinguistic comments, in that their refugee status is questioned, and the people themselves delegitimised, by putting the word 'refugees' in quotation marks or pre-modifying it by 'so-called.'

Identification, collectivisation and aggregation of migrants are illustrated in examples (10)-(12):

(10) Flüchtlinge aus sicheren Drittstaaten bekommen kein Asyl.

[Refugees from safe third countries are not granted asylum.]

(11) Ich hätte sie fast gewählt, weil alle anderen etablierten Parteien null Ehrgeiz gezeigt haben, die illegalen Flüchtlingsrouten dicht zu machen und abgelehnte Asylbewerber ausnahmslos abzuschieben.

[I almosted voted for [the AfD], because all other established parties have shown zero ambition to close the illegal refugee routes and to deport all refuted asylum seekers without exception.]

(12) Ich möchte keine Flüchtlinge millionenweise in diesem Land.

[I don't want millions of refugees in this country.]

While this pattern is similar to that for politicians and voters, it should be noted that the last form of representation, i.e. aggregation, is much higher for migrants than for politicians and or voters (see Figure 1). This corroborates KhosraviNik's 
$(2010,13)$ finding that refugees, asylum seekers and migrants are 'depersonalized, dehumanized and objectified as numbers and figures', and is further emphasised by the fact that migrants are the only one of the three groups that are not individualised at all.

By contrast, individualisation is joint third for politicians (9.26 percent). As for migrants, identification is the most common form of representing politicians (48.15 percent), followed by collectivisation (25.93 percent). The three kinds of representation are exemplified below.

(13) Ich schäme mich für unsere Politiker, die nicht nur schlechte Verlierer, sondern Verächter ihrer eigenen Kultur und Beförderer des Untergangs unserer Lebensweise sind.

[I am ashamed of our politicians, who are not only bad losers but are also in contempt of their own culture and promote the decline of our lifestyle.]

(14) Außerdem sollten sich die Politiker ihrem Volk verpflichtet fühlen und schauen wieviel Hilfe [für Flüchtlinge] möglich ist ohne unser Land zu Grunde zu richten.

[Also, politicians should feel accountable to their people and see how much help [for refugees] is possible without ruining our country.]

(15) Der mediale Umgang mit der AFD und der Versuch, das kleinste Fehlvergehen eines AFD-Politikers ... hochzustilisieren, hat mich dazu bewogen, dem Schwächeren, namentlich der AFD, mit meiner Stimme zu helfen.

[The way the media treated the AfD and the attempt to blow up the slightest error of judgement by an AfD politician ... has made me lend my vote to the weaker party, namely the AfD.]

Example (13) identifies politicians from traditional parties - referred to in the first person - as adversaries of the people, while example (14) ascribes an obligation to them. This classical strategy of populist discourse is here complemented by constructing the AfD as a victim of the media. In this context, it can also be noted that politicians are rarely referred to as 'people' ('Menschen,' 'Leute'); it seems as though their professional identity eclipses other aspects of them.

Finally, voters are mostly identified as supporters of particular parties (39.51 percent) as well as being collectivised (20.99 percent). In contrast to the other two groups, however, they are also frequently genericised (22.22 percent) through singular forms, as in example (16):

(16) Ein anderes, wichtigeres Thema wäre die Verlängerung der Wahlperiode auf 5 Jahre, was natürlich einer weiteren Entmachtung des Wählers gleichkäme. 
[Another important topic would be the extension of the legislative period to 5 years, which would of course mean a further disempowerment of the voter.]

This AfD supporter constructs 'the voter' as a prototype that we can assume to stand in for themselves as powerless in the face of established parties. The example is therefore another illustration of a populist discursive strategy.

Moving on to appraisal, it is worth noting that in proportion to how often they are referenced, politicians are the most appraised group (86.96 percent of all mentions are evaluative), with voters and migrants trailing far behind (47.67 and 41.8 percent, respectively). Migrants and politicians differ from each other in that evaluation is considerably more varied for the former than for the latter, with more appraisal categories being realised. However, negative evaluation is predominant for both groups, especially negative propriety. The following examples show how migrants and politicians are constructed as immoral:

(17) Wenn Leute in Deutschland keine Notwendigkeit sehen Deutsch zu lernen läuft etwas falsch.

[When people in Germany see no need to learn German something is going wrong.]

(18) Bürger, die Kritik üben, werden von Politikern bepöbelt! ..., genauso wie von den Medien.

[Critical citizens are insulted by politicians ... and media alike.]

About a quarter of all evaluations of migrants sees them harmful and an equal percentage casts politicians as incapable. As shown in example (20), the two can also be combined.

(19) [Mein] Hauptgrund [für die Wahl der AfD ist] [u]nkontrollierter Zustrom von Flüchtlingen in unser Land.

[[My] main reason [for voting AfD is the] uncontrolled influx of refugees into our country.]

(20) Fast 2 Millionen Araber ins Land zu holen [ist] nicht besonders klug.

[[It's] not very smart to bring nearly 2 million Arabs into the country.]

It is striking that there is practically no affect to be found in the appraisal of either migrants or politicians, suggesting a lack of empathy for groups that are constructed as out-groups and adversaries.

Given that reference to voters often includes the contributing AfD supporters themselves, it is unsurprising to see a very different pattern of evaluation for 
that social actor group. While a quarter of appraisal instances is again for negative propriety, it is voters for other parties that are thus represented as immoral. This is followed by around 22 percent each for negative and positive capacity, but negative capacity especially of AfD voters is often ascribed as a view to others, while voters in general are presented as powerful.

(21) [Ich habe AfD gewählt] [w]eil die etablierten Parteien ... den Wähler ... als schlecht informiert darstellen

[[I voted AfD because] the established parties ....represent [its] voters ... as ill-informed.]

(22) Schließlich ist der Wähler der Souverän.

[The voter is sovereign after all.]

Crucially, we find some instances of affect, mostly dissatisfaction, in the appraisal of voters as well, and it is safe to say that commenters here project their own feelings onto a social actor group referred to in the third person.

Given that the treatment of the AfD by the media was one of the main voting motivations, the way they are evaluated is worth a brief look. Table 2 shows the most significant collocates of 'media' ('Medien') in our corpus.

Ignoring metadata ('online') and function words ('den'/'the'), the top ten collocates are 'election campaign,' 'coverage,' 'agitation,' 'treatment,' 'parties,' 'against,' 'other' and 'German.' This list already indicates a scenario in which, in the run-up to the 2017 general election, media coverage was characterised by agitating against someone, presumably the AfD, and by an adversarial stance.

Table 2: Collocates of 'media' ('Medien') in the online vox pop.

\begin{tabular}{llllll}
\hline \multicolumn{2}{l}{ Total no. of collocate types: 61} & & \multicolumn{2}{l}{ Total no. of collocate tokens: 472} \\
\hline Rank & Freq & Freq (L) & Freq (R) & Stat & Collocate \\
1 & 4 & 2 & 2 & 8.41579 & wahlkampf \\
2 & 3 & 3 & 0 & 7.41579 & online \\
3 & 3 & 3 & 0 & 7.41579 & berichterstattung \\
4 & 3 & 2 & 1 & 7.30031 & hetze \\
5 & 3 & 3 & 0 & 6.30031 & umgang \\
6 & 12 & 7 & 5 & 5.71535 & parteien \\
7 & 9 & 1 & 8 & 5.47719 & gegen \\
8 & 6 & 1 & 5 & 5.40084 & anderen \\
9 & 4 & 3 & 1 & 5.37140 & deutschen \\
10 & 29 & 22 & 7 & 5.29363 & den \\
\hline
\end{tabular}


('German' is a pre-modifier in 'German media.') This is indeed borne out by the respective concordances; we present a few typical examples below.

(23) Und die Medien haben einen Wahlkampf nur gegen die AfD betrieben.

Die ständige Hetze durch die Medien ... gegen diese neue Partei fand ich ziemlich abscheulich.

[And the media ran an election campaign solely against the AfD.

I found the constant media ... agitation against this new party rather disgusting.]

(24) Was mich in meiner Wahl vor allem bestärkt hat, ist der arrogante Umgang von Medien ... mit einer demokratisch legitimierten Partei.

[What most encouraged me in my vote was the arrogant media ... treatment of a democratically legitimised party.]

In this construction of the $\mathrm{AfD}$ and its voters - i.e. the commenters - as victims, the media are appraised as tenacious but immoral.

To summarise, the main social actors mentioned by AfD supporters are migrants, politicians, voters and the media. No group is referred to more often than migrants, who are frequently represented in terms of numbers and are mostly evaluated as immoral and harmful. Neither migrants nor politicians are ascribed any emotions, and the latter are very rarely referred to as 'people' either. While the language used about politicians is rather formulaic, they attract most evaluative comment, and are regarded as immoral and incompetent. In addition, they are cast as not acting in the interest of the German people. Voters are the most heterogeneous group of social actors, chiefly because it includes both AfD voters, who are presented as dissatisfied and as victimised by a tenacious but immoral media, and supporters of other parties, who are likewise appraised as immoral. Importantly, voters as such are posited as powerful but not served by established politicians and, if they support the AfD, as persecuted by the media. This realises a typical populist discursive strategy that pits 'the people' against the establishment.

In the last section, we will reflect on what our findings suggest about drivers of the right-wing populist vote across national contexts.

\section{Discussion}

Our analysis of the ZON online vox pop reveal three main drivers for voting AfD. One crucial motivation for supporting AfD is discontent with the political system, 
in particular with the government and its work. There is a strong personal focus on Chancellor Angela Merkel and criticism of her stance towards immigration politics since 2015. Putting this into a populist context, instead of a party leader of the rightpopulist party AfD being cast as a hero and as such a crucial voter motivation, the focus is turned towards Ms Merkel and her wrong-doings instead. She is portrayed as an 'anti-hero' and therefore an important factor for voters' decision to support the AfD. The voters' perception of the media's negative treatment of the AfD and particularly its supporters by regarding them as 'nazis' is another reason for supporting AfD. This resembles the stance of 'now more than ever,' a familiar reaction of groups when they feel threatened by an Other. In this case, it is the mainstream media, which in a populist context can be regarded as the 'elite' and 'enemy of the people.' Further, in populist contexts an 'outside enemy' is also constructed and the third main voting motivation belongs to this category, i.e. migrants and migration policy as decisive drivers for supporting a right-wing populist party.

The AfD has been deemed 'Eurosceptic and right-wing populist' by political rivals and mainstream media (Arzheimer 2015, 536) and our findings show that AfD voters indeed recontextualise populist concepts in their motivations for supporting the party. Taking the findings to a more international level and referring to our own work on vox pops with intended Leave voters in the run-up to the 2016 'Brexit' referendum (Miglbauer and Koller 2019), we can see shared reasons for voting for right-wing populist parties and causes in Germany and the UK. Voters in both countries show an in-group bias and put 'emphasis on "smaller life worlds"' (Heinisch 2008, 49) in their rejection of migrants and refugees. While the rejection of the Other as morally deficient is also prevalent in both contexts, there are differences in who the Other is. In the AfD data, it is politicians and media, while in the UK it is the European Union that are constructed as the Other. Another factor that Leave and AfD voters have in common is the perception of the status quo as unmanageable and, in the AfD data, as unbearable. Voting for rightwing populist parties and causes results in increased capability among voters who hope to bring about change in the political landscape.

The analysis also reveals a change in the voter profile. Previous research has found that voters of right-wing populist parties tend to attract low-income men (Storz and Kahrs 2016), but as far as economic factors are concerned, this is clearly not the case for the AfD voters responding to ZON's question. In fact, such perceptions are explicitly contested by some AfD voters in the vox pop, as are perceptions of them being right-wing or 'nazis.' One vox pop contributor summarises it aptly:

Es war eine verspätete Abstimmung über Merkels Migrationspolitik. Da haben keine sozialen Verlierer sich von der CDU abgewendet sondern viele Normalbürger denen es einfach zu bunt 
wurde und die Partei die 'Merkel-muss-weg im Programm hat, gewählt haben. Dabei ging es nicht um Materialismus sondern Identität.

[It was a late poll on Merkel's immigration policy. It is not socio-economic losers who turned their back on the CDU but many average citizens who just had enough and voted for the party which had 'Merkel-needs-to-leave' in their manifesto. The election was not about materialism but about identity.]

While the contributors to the vox pop are perhaps not representative of AfD voters more broadly, the sheer number of responses from such non-representative supporters suggests that here we have a right-wing populist party that has clearly widened is appeal beyond its core clientele. It remains to be seen how sustainable that support will be as contextual parameters change.

\section{Works Cited}

Albertazzi, Daniele and Duncan McDonnell (2008). "Introduction: The Sceptre and the Spectre." Albertazzi Daniele and Duncan McDonnell, eds. Twenty-first Century Populism: The Spectre of Western European Democracy. Basingstoke: Palgrave Macmillan, 1-14.

AfD (Alternative für Deutschland) (2016). Unser Grundsatzprogramm für Deutschland. Online: https://www.afd.de/grundsatzprogramm/, accessed 7 July 2019.

AfD (Alternative für Deutschland) (2019). AfD startet mit über 35.000 Mitgliedern und Förderern ins Super-Wahljahr 2019. Online: https://www.afd.de/afd-startet-mit-ueber-35-000mitgliedern-und-foerderern-ins-super-wahljahr-2019/, accessed 7 July 2019.

Arzheimer, Kai (2015). “The AfD: Finally a Successful Right-Wing Populist Eurosceptic Party for Germany?" West European Politics 38.3, 535-556.

Beckers, Kathleen and Raymond A. Harder (2016). “'Twitter Just Exploded': Social Media as Alternative Vox Pop.” Digital Journalism 4.7, 910-920.

Billiet, Jaak and Hans De Witte (1995). “Attitudinal Dispositions to Vote for a 'New' Extreme Right-Wing Party: The Case of 'Vlaams Blok'." European Journal of Political Research 27.2, 181-202.

Decker, Frank (2008). “Germany: Right-Wing Populist Failures and Left-Wing Successes.” Albertazzi, Daniele and Duncan McDonnell, eds. Twenty-First Century Populism: The Spectre of Western European Democracy. Basingstoke: Palgrave Macmillan, 119-134.

Demata, Massimiliano (2019). "The Referendum Result Delivered a Clear Message: Jeremy Corbyn's Populist Discourse.” Veronika Koller, Susanne Kopf and Marlene Miglbauer, eds. Discourses of Brexit. Abingdon: Routledge, 123-139.

Denver, David, Christopher Carman, Rob Johns (2012). Elections and Voters in Britain. Basingstoke: Palgrave Macmillan.

DIW (Deutsches Institut für Wirtschaftsforschung) (2017). Wählerschaft der Parteien. Online: https://www.diw.de/documents/publikationen/73/diw_01.c.562050.de/17-29.pdf, accessed 7 July 2019.

Freeden, Michael (2017). “After the Brexit Referendum: Revisiting Populism as an Ideology.” Journal of Political Ideologies 22.1, 1-11. 
Gabrielatos, Costas and Paul Baker (2008). "Fleeing, Sneaking, Flooding: A Corpus Analysis of Discursive Constructions of Refugees and Asylum Seekers in the UK Press, 1996-2005.” Journal of English Linguistics 36.1, 5-38.

Hawkins, Kirk A. (2009). “Is Chávez Populist? Measuring Populist Discourse in Comparative Perspective." Comparative Political Studies 42.8, 1040-1067.

Heinisch, Reinhard (2008). "Austria: The Structure and Agency of Austrian Populism.” Daniele Albertazzi and Duncan McDonnell, eds. Twenty-First Century Populism: The Spectre of Western European Democracy. Basingstoke: Palgrave Macmillan, 67-83.

Inglehart, Ronald F. and Pippa Norris (2016). "Trump, Brexit, and the Rise of Populism: Economic have-nots and Cultural Backlash." Harvard Kennedy School Working Paper Series. Online: https://faculty.uml.edu/sgallagher/Trump_Populism_Norris.pdf, accessed 7 July 2019.

Jowett, Garth and Victoria O'Donnell (2015). Propaganda and Persuasion. 6th ed. Thousand Oaks, CA: SAGE.

Kazin, Michael (1995). The Populist Persuasion: An American history. Ithaca, NY: Cornell University Press.

KhosraviNik, Majid (2010). "The Representation of Refugees, Asylum Seekers and Immigrants in British Newspapers: A Critical Discourse Analysis.” Journal of Language and Politics 9.1, 1-28.

Kranert, Michael (2019). "Populist Elements in the Election Manifestoes of AfD and UKIP." Zeitschrift für anglistik und amerikanistik 67.3, 265-282.

Kritzinger, Sylvia, Michael S. Lewis-Beck, Richard Nadeau and Eva Zeglovits (2013). The Austrian Voter. Göttingen: V\&R Unipress.

Kwasniewski, Nicolai (2017). Wie Gehalt, Beruf und Wohnort die Wahlentscheidung prägen. Online: https://www.spiegel.de/wirtschaft/soziales/bundestagswahl-2017-wer-waehltcdu-csu-spd-fdp-gruene-linke-afd-a-1158543.html, accessed 7 July 2019.

Lewis, Justin M.W., Sanna Inthorn and Karin Wahl-Jorgensen (2005). Citizens or Consumers? What the Media Tell Us About Political Participation. Maidenhead: Open University Press.

Lubbers, Marcel and Peer Scheepers (2000). "Individual and Contextual Characteristics of the German Republikaner Vote: A Test of Complementary Theories." European Journal of Political Research 38.1, 63-94.

Martin, James R. and Peter R. R. White (2005). Appraisal in English. Basingstoke: Palgrave Macmillan.

Mayer, Nonna and Pascal Perrineau (1992). “Why Do They Vote for Le Pen?” European Journal of Political Research 22.1, 123-141.

Miglbauer, Marlene and Veronika Koller (2019). “'The British People Have Spoken’: Voter Motivations and Identities in Vox Pops on the British EU Referendum." Veronika Koller, Susanne Kopf and Marlene Miglbauer, eds. Discourses of Brexit. Abingdon: Routledge, 86-103.

Mudde, Cas (2004). “The Populist Zeitgeist.” Government and Opposition 39.4, 542-563.

Mudde, Cas and Cristóbal Rovira Kaltwasser (2017). Populism: A Very Short Introduction. Oxford: Oxford University Press.

Myers, Greg (2004). Matters of Opinion: Talking About Public Issues. Cambridge: Cambridge University Press.

Oesch, Daniel (2008). “Explaining Workers' Support for Right-Wing Populist Parties in Western Europe: Evidence from Austria, Belgium, France, Norway, and Switzerland.” International Political Science Review 29.3, 349-373.

Pfahl-Traughber, Armin (2017). Wer wählt warum die AfD? Online: https://www.bpb.de/politik/ extremismus/rechtspopulismus/248916/wer-waehlt-warum-die-afd, accessed 7 July 2019. 
Schröder, Jens (2012). Analyse: Der typische Zeit-Online-Leser. Online: https://meedia. de/2012/11/30/analyse-der-typische-zeit-online-leser/, accessed 7 July 2019.

Spruyt, Bram, Gil Keppens, and Filip Van Droogenbroeck (2016). "Who Supports Populism and What Attracts People to It?" Political Research Quarterly 69.2, 335-346.

Statista (2019). Anzahl der Sitze der AfD in den Landtagen der Bundesländer in Deutschland (Stand: Oktober 2018). Online: https://de.statista.com/statistik/daten/studie/606307/ umfrage/sitze-der-afd-in-den-landtagen-der-bundeslaender-in-deutschland/, accessed 7 July 2019.

Storz, Wolfgang and Horst Kahrs (2016). Wer wählt die AfD - und warum? Online: https:// oxiblog.de/wer-waehlt-die-afd/, accessed 7 July 2019.

The Brexit Party (2019). Today the Fight for Brexit Begins. Online: https://thebrexitparty.org/ today-the-fight-for-brexit-begins/, accessed 7 July 2019.

Tolson, Andrew (2019). “'Out Is out and That's It the People Have Spoken’: Uses of Vox Pops in UK TV News Coverage of the Brexit Referendum.” Critical Discourse Studies 16.4, 420-431.

UKIP (UK Independence Party) (2018). Policies for the People. Online: https://www.ukip.org/ pdf/UKIP_Manifesto_Sept_2018.pdf, accessed 7 July 2019.

van Leeuwen, Theo (2008). Discourse and Practice: New Tools for Critical Discourse Analysis. Oxford: Oxford University Press.

'Why I voted for UKIP' (2014). Online: https://www.bbc.co.uk/news/uk-politics-27584237, accessed 7 July 2019.

Wodak, Ruth (2015a). “Normalisierung nach rechts”: Politischer Diskurs im Spannungsfeld von Neoliberalismus, Populismus und kritischer Öffentlichkeit. Linguistik Online 73.4, 27.

Wodak, Ruth (2015b). The Politics of Fear: What Right-Wing Populist Discourses Mean. Los Angeles: SAGE.

Wodak, Ruth, Majid KhosraviNik and Brigitte Mral, eds. (2013). Right-Wing Populism in Europe. London: Bloomsbury.

ZON (Zeit online) (2017). Warum haben Sie die AfD gewählt? Online: https://www.zeit.de/ politik/deutschland/2017-09/wahlentscheidung-warum-afd-gewaehlt, accessed 7 July 2019. 